\title{
EFEKTIVITAS DAN EFEK SAMPING PENGGUNAAN GABAPENTIN PADA PASIEN NEUROPATI DIABETIK DI RSUP DR. WAHIDIN SUDIROHUSODO MAKASSAR
}

\author{
Zhulhajsyirah ${ }^{1}$, Elly Wahyudin ${ }^{1}$, Jumraini Tammass \\ ${ }^{1}$ Fakultas Farmasi, Universitas Hasanuddin, Makassar \\ ${ }^{2}$ Fakultas Kedokteran, Universitas Hasanuddin, Makassar
}

Kata Kunci :

Neuropati diabetik, gabapentin, efek terapi, efek samping

\begin{abstract}
ABSTRAK
Penelitian ini bertujuan untuk mengetahui dan menganalisis efektivitas penggunaan gabapentin terhadap penurunan derajat nyeri pada pasien neuropati diabetik di RSUP Wahidin Sudirohusodo Makassar yang diukur dengan menggunakan instrumen Numerical Pain Rating Scale (NPRS) efek samping penggunaan gabapentin pada pasien neuropati diabetik di RSUP DR. Wahidin Sudirohusodo Makassar. Penelitian ini dilaksanakan di Poliklinik Saraf dan Poliklinik Endokrin Instalasi Rawat Jalan RSUP DR. Wahidin Sudirohusodo Makassar pada bulan april-juni 2018. Jenis penelitian ini adalah penelitian observasional non eksperimental dengan desain penelitian cros sectional. Metode yang digunakan dalam penelitian ini adalah dengan melakukan wawancara dan pengukuran skala nyeri pada pasien neuropati diabetik. Data dianalisis dengan menggunakan analisis statistik uji Wicoxon Signed Ranks Test. Hasil penelitian menunjukkan bahwa efek terapi gabapentin sebelum dan sesudah pemberian pada 21 pasien neuropati diabetik menunjukkan adanya penurunan skala nyeri dengan penurunan rata-rata sebesar 2,14 dengan nilai $p$-value $<0,05$ yang berarti berbeda secara signifikan dalam menurunkan nyeri neuropati. Sedangkan Efek Samping yang terjadi setelah pemberian gabapentin yaitu, mengantuk dan pusing $14 \%$, mengantuk $29 \%$, pusing $5 \%$ dan tidak mengalami efek samping $52 \%$.
\end{abstract}

\section{PENDAHULUAN}

Diabetes mellitus adalah kondisi dimana terjadi gangguan dalam mengubah glukosa menjadi energi sehingga terjadi peningkatan glukosa dalam darah (hiperglikemia) dan dapat juga memunculkan gejala (1). Penderita Diabetes melitus yang tidak melakukan kontrol glukosa dengan rutin dan baik akan menyebabkan timbulnya komplikasi vaskular. Komplikasi vaskular ini dibedakan menjadi dua yaitu, makrovaskular (penyakit jantung koroner, stroke) dan mikrovaskular (retinopati, nefropati, dan neuropati) (2). Insidensi neuropati diabetik terjadi antara $60 \%$ sampai $70 \%$ pada pasien DM tipe I dan tipe II dengan adanya komplikasi neurologi (3). Studi cohort pada 4400 pasien di Belgia, menemukan bahwa $7,5 \%$ responden memiliki neuropati pada awal didiagnosis DM. Setelah 25 tahun, pasien dengan neuropati diabetik naik menjadi 45\%. Sedangkan Insidensi di Inggris, prevalensi neuropati diabetik di antara populasi pasien di rumah sakit tercatat sekitar $29 \%$ mengalami neuropati perifer diabetik (4).

Neuropati diabetik terus memberikan suatu tantangan teurapeutik yang sepenuhnya belum dipahami serta efektivitas pereda nyeri yang kurang memuaskan. Terapi simptomatis adalah terapi farmakologis selain pengontrolan gula darah secara ketat (5). Ada beberapa jenis obat yang digunakan secara tunggal maupun kombinasi, telah menunjukkan penurunan nyeri neuropati yang bermakna dibandingkan dengan placebo. Pada beberapa study klinis, terapi simptomatis dikatakan berhasil jika dapat menurunkan nyeri sampai 50\%. (6).
Ada beberapa pedoman terapi yang merekomendasikan penggunaan terapi farmako-logi yang telah disetujui dan juga obat-obat off-label untuk mengurangi rasa nyeri dan mening-katkan kualitas hidup pasien. Terapi tersebut antara lain, golongan antikonvulsan, antidepresan, analgetik dan obat-obatan topical $(4,7)$.

Menurut American Diabetes Asosiation (ADA) 2011, merekomendasikan penggunaan amitriptilin, nortriptilin, imipramin, Gabapentin, Carbamazepin, pregabalin, duloxetin untuk manajemen neuropati diabetik, tanpa pembagian pilihan utama berdasarkan level bukti yang terkuat. Menurut Boulton, 2003, Gabapentin merupakan terapi lini pertama untuk neuropati diabetik di United Kingdom dan pada umumnya ditoleransi lebih baik dibanding Three Cyclic Antidepresant (TCA). Selain itu menurut Haslam dan Nurmikko, 2008, dibutuhkan terapi untuk mengontrol nyeri pada pasien diabetes sehingga TCA tetap sebagai pendekatan lini pertama dengan gabapentin sebagai alternatif untuk TCA. Tetapi dengan melihat efek samping dari TCA, gabapentin adalah terapi utama pada pasien lansia dengan neuropati diabetik.

Gabapentin adalah obat yang digunakan sebagai anti epilepsi tapi sekarang juga direkomendasikan sebagai lini pertama pada nyeri neuropati, termasuk neuropati diabetik dan post herpetic neuralgia. (10). Antikonvulsan gabapentin memiliki struktur yang analog dengan Gamma Amino Butiric Acid (GABA) dan berperan dalam meningkatkan konsentrasi serta kecepatan sintesis GABA 
pada otak. Walaupun mekanisme efek analgesik gabapentin belum diketahui tapi diperkirakan gabapentin bekerja pada berbagai reseptor di daerah pusat (multiple central sites). Gabapentin bekerja dengan cara mengatur aliran kalsium dalam sel sehingga menurunkan firing of the transmission cell dan menurunkan pelepasan monoamine neurotransmitter (11). Pada nyeri neuropati, Gabapentin berperan dengan mengembalikan sistem penghambatan endogen (endogenous inhibitory systems) yaitu senyawa yang berperan pada jalur penghambatan descending (descending or local inhibitory pathways) (12). Jika dibandingkan senyawa opioids, keunggulan dari senyawa yang bekerja pada sistem GABA-ergic adalah pada penggunaan berulang atau jangka panjang tidak menyebabkan toleransi ataupun suatu ketergantungan (addiction) (13). Mengingat nyeri neuropati diabetik merupakan penyakit yang bersifat kronik, maka penggunaan senyawa yang bekerja pada sistem GABAergic seperti gabapentin akan lebih menguntungkan. Sejak tahun 2011 gabapentin telah mendapatkan persetujuan dari FDA sebagai obat on-label dengan indikasi nyeri neuropati (14).

Gangguan nyeri neuropati pada pasien diabetes telah dilaporkan dapat mengurangi kualitas hidup yang mempengaruhi suasana hati, tidur, dan aktivitas sehari-hari sehingga menjadi penting untuk menilai intensitas, kualitas nyeri, dan sensasi abnormal. Intensitas nyeri dapat dilakukan dengan berbagai macam skala baik itu verbal, numerical ataupun visual. Biasanya sensasi abnormal yang dirasakan pasien nyeri neuropatijuga dapat dinilai kualitasnya dengan kuesioner nyeri neuropati sehingga perlu diukur untuk mendukung apakah penggunaan gabapentin secara efektif dapat meredakan nyeri neuropati serta bagaimana efek samping dari obat tersebut pada penggunaan jangka waktu yang lama pada pasien diabetes berhubung neuropati diabetes merupakan penyakit kronis yang nantinya efek samping tersebut dapat mempengaruhi kualitas hidup pasien.

\section{METODE PENELITIAN}

\section{Rancangan Penelitian}

Jenis penelitian ini adalah penelitian observasional non eksperimental. Desain penelitian ini adalah cros sectional. Pengambilan sampel menggunakan teknik non-probability sampling dengan cara consecutive sampling. Subjek penelitian adalah pasien neuropati diabetik pada poliklinik saraf dan poliklinik endokrin di RSUP Wahidin Sudirohusodo Makassar.

\section{Lokasi dan Waktu Penelitian}

Penelitian ini dilaksanakan pada bulan April-Juni 2018 dan lokasi penelitian di poliklinik saraf dan poliklinik endokrin RSUP DR Wahidin Sudirohusodo Makassar.

\section{Bahan Penelitian}

Bahan penelitian berupa Rekam Medik pasien dan instrument penelitian yang berisi format wawancara pasien dan instrumen Numerical Pain Rating Scale (NPRS).

\section{Prosedur Kerja}

Pengambilan data pada rekam medik yaitu no. RM, umur, jenis kelamin, alamat, profil pengobatan, profil penyakit, dan awal peresepan gabapentin.

Wawancara pada pasien berdasarkan instrumen penelitian yaitu pendidikan, pekerjaan, Awal menderita neuropati diabetik, penyakit komplikasi, karakteristik nyeri yang dirasakan, pengukuran derajat nyeri dengan instrumen Numerical Pain Rating Scale (NPRS) sebelum dan setelah pemberian gabapentin serta efek samping yang dirasakan setelah pemberian gabapentin.

\section{Analisis dan Penyajian Data}

Analisis data pada penelitian ini dilakukan dengan menggunakan analisis deskriptif mengenai karakteristik subyek yang disajikan dalam bentuk tabel dan narasi. Analisis Data hasil pengukuran derajat nyeri dengan menggunakan Numerical Pain Rating Scale (NPRS), dikumpulkan, dan diolah dengan metode statistik uji Wilcoxon Signed Ranks Test.

\section{HASIL DAN PEMBAHASAN}

Penelitian ini merupakan penelitian observasional non eksperimental yaitu peneliti tidak memberikan perlakuan pada sampel. Peneliti hanya melakukan observasi berdasarkan peresepan dari dokter dalam hal ini peresepan gabapentin. Desain penelitian ini adalah cros sectional yaitu studi observasional yang hanya dilakukan sekali sesuai dengan waktu yang telah ditentukan dengan melihat adanya hubungan antara variabel dependen dan variabel independen (15). Sampel pada penelitian ini adalah pasien yang mengalami neuropati diabetik pada poli endokrin dan poli saraf di RSUP DR Wahidin Sudirohusodo Makassar yang berjumlah 21 pasien.

\section{Karakteristik Pasien berdasarkan usia}

Pada penelitian ini, usia pasien atau sampel penelitian dikategorikan menjadi 3 tingkat usia, yaitu: usia $<40$ tahun, usia 40-60 tahun, dan usia $>60$ tahun. Sampel yang berusia kurang dari 40 tahun tidak ada, sedangkan untuk pasien yang berusia 40-60 tahun terdapat 9 orang dan 12 orang berusia > 60 tahun. Variabel yang sangat penting dalam menilai respon nyeri adalah umur. Cara merespon pasien yang lebih muda berbeda dengan pasien yang lebih tua. Pasien yang lebih tua kadang mengabaikan rasa nyeri bahkan menahannya walaupun mengalami penurunan persepsi sensorik stimulus karena mereka menganggap nyeri adalah hal alamiah yang harus dijalani. Selain itu pada pasien lansia mengalami peningkatan ambang nyeri serta perubahan neurofisiologis (19). Hasil wawancara yang dilakukan, rata-rata pasien sudah lanjut usia yaitu diatas 46 tahun. Hal tersebut memungkinkan pasien menggunakan kata-kata umum untuk menggambarkan perasaan mereka.

\section{Karakteristik Pasien berdasarkan jenis kelamin}

Pada penelitian ini sampel laki-laki lebih banyak dibanding sampel perempuan. Berdasarkan hasil wawancara yang dilakukan, pasien wanita lebih dapat menunjukkan ekspresi emosional yang kuat dibanding pasien laki-laki sehingga dapat lebih mudah menentukan skala nyeri dengan NPRS. Pasien laki-laki memiliki sensitifitas yang lebih rendah (kurang mengekspresikan rasa nyeri yang dirasakan secara berlebihan dibandingkan wanita (2). Jenis kelamin juga bukan merupakan faktor pendukung terjadinya neuropati diabetik.

\section{Karakteristik Pasien berdasarkan tingkat pendidikan}

Pada penelitian ini karakteristik pendidikan dibagi menjadi 5 kategori yaitu, SD, SLTP, SLTA, D3 dan S1. 1 pasien dengan tingkat pendidikan SD, 12 pasien SLTA dan 8 pasien S1. Tingkat pendidikan memberikan pengaruh dalam memberikan respon dari luar, yaitu pada pasien yang memiliki pendidikan yang lebih tinggi dapat memberikan respon yang lebih rasional dan lebih cepat paham dibandingkan pasien yang memiliki tingkat pendidikan yang lebih rendah, sehingga diperlukan suatu pendekatan bahasa yang lebih sederhana dan dapat dipahami oleh pasien dengan tingkat pendidikan yang lebih rendah. Tingkat pendidikan juga tidak berpengaruh pada intensitas nyeri (16), hanya 
pada cara memberikan respon pada saat wawancara pada pasien.

\section{Karakteristik nyeri}

Karakteristik nyeri yang paling banyak dirasakan oleh pasien adalah rasa kram pada tangan dan kaki. Selain itu karakteristik nyeri yang lain yang juga dirasakan ole pasien adalah nyut-nyut, seperti tertusuk pisau, rasa kaku, rasa panas, rasa berat dan nyeri jika disentuh. Gejala tersebut di atas sudah sesuai dengan gejala utama neuropati diabetik yaitu parestesia (sensasi abnormal berupa kesemutan, seperti tertusuk, atau seperti terbakar pada kulit yang umumnya dirasakan di tangan, kaki, lengan dan tungkai), mati rasa, atau nyeri yang mungkin merupakan gejala utama. Nyeri terjadi lebih dominan pada kaki dari pada tangan (20) Nyeri neuropati disebabkan oleh adanya lesi pada sistem saraf pusat dan atau perifer yang bersifat hilang timbul dan konstan serta bersifat epikritik atau tajam dan menyetrum yang ditimbulkan oleh rusaknya serabut $A \delta$ dengan lokasi yang tidak jelas yang disebabkan oleh serabut $C$ yang abnormal (4)

\section{Efek Samping Obat}

Pada penelitian ini, monitoring efek samping obat dilakukan pada semua pasien yaitu 21 orang pasien. Dari monitoring efek samping gabapentin yang dilakukan, ada 3 pasien mengalami mengantuk dan pusing, 6 pasien mengantuk, 1 pasien pusing, dan 11 pasien tidak mengalami efek samping. Hal tersebut terjadi karena respon setiap orang terhadap suatu obat berbeda-beda olehnya itu ada pasien yang mengalami efek samping obat tapi ada juga yang tidak mengalami efek samping obat. Hal tersebut sudah sesuai dengan Efek samping yang umum dialami pada pemakaian gabapentin adalah pusing $(23,9 \%)$, somnolen $(27,4 \%)$, ataxia $(7,1 \%)$, edema perifer $(9,7 \%)$ dan kebingungan (17). Pada penelitian ini efek samping yang terjadi pada pasien kelompok gabapentin adalah pusing dan mengantuk, hal ini dapat terjadi karena Gabapentin memiliki mekanisme kerja alternatif pada sistem saraf pusat dengan cara berikatan pada sub unit $\alpha 2 \delta$ voltage dependent calcium channels (VDCC), menghambat influx $\mathrm{Ca}^{2+}$ pada post sinaps atau menghambat influx $\mathrm{Ca}^{2+}$ presinaps, kemudian menghambat pelepasan neurotransmitter eksitatory sehingga menumpulkan transmitsi sinaptik. Hal tersebut menyebabkan penurunan pelepasan neurotransmitter eksitatory yaitu neurotransmitter glutamat dan neurotransmitter noradrenalin. Pada sistem saraf pusat neurotransmitter glutamat memegang peranan penting. Adanya penurunan glutamat menyebabkan suatu penurunan aktivasi reseptor alpha-amino-3-hydroxy-5methyl-4-isoxasole propionic acid (AMPA) pada otak. Sedangkan neurotransmitter nooradrenalin adalah suatu neurotransmitter di sistem saraf pusat dan bertindak sebagai hormon jika dilepaskan dari glandula medula. Korteks serebral, batang otak dan sistem limbik dihubungkan oleh Noradrenergik pathways. Nooradrenalin mempunyai peran dalam mengatur sekresi glandula pituitary dan menentukan tingkat kewaspadaan. Adanya penurunan neurotransmitter noradrenalin pada otak mengakibatkan penurunan tingkat kewaspadaan seperti mengantuk dan pusing.

Tabel 1. Hasil Analisis perbandingan skala nyeri sebelum dan setelah pemberian Gabapentin

\begin{tabular}{lccccc}
\hline & N & Mean & $\begin{array}{c}\text { Std. } \\
\text { Deviation }\end{array}$ & Min & Max \\
\hline Sebelum & 21 & 3.2857 & .56061 & 3.00 & 5.00 \\
Sesudah & 21 & 1.1429 & .47809 & .00 & 2.00 \\
\hline
\end{tabular}

\section{Pengukuran Skala Nyeri}

Pasien yang menjadi sampel pada penelitian ini adalah pasien yang mendapat peresepan obat lebih dari 1 bulan karena gabapentin baru dapat dirasakan efeknya setelah 1-2 minggu pemakaian (18). Pada penelitian ini dilakukan wawancara pada pasien yang masuk dalam kriteria inklusi dan bersedia menjadi sampel penelitian. Pasien kemudian dilakukan wawancara yang salah satunya adalah efek samping obat dan pengukuran derajat nyeri sebelum dan sesudah minum obat. Dari hasil pengukuran derajat nyeri dapat dilihat bahwa terdapat 16 pasien dengan nyeri ringan (skala 3), dan 5 pasien dengan nyeri sedang (skala 4 dan 5) dengan skala penurunan nyeri rata-rata 2,14 . Hasil analisis statistik dengan uji Wicoxon Signed Ranks test sebelum dan setelah pemberian gabapentin adalah nilai Asymp Sig $=0.000$ (p < 0.05 ) yang berarti penurunan skala nyeri berbeda secara statistik atau signifikan dalam menurunkan nyeri neuropati. Gabapentin pada neuropati diabetik menurunkan derajat nyeri pada sistem saraf pusat dengan cara berikatan pada sub unit $\alpha 2 \delta$ voltage dependent calcium channels (VDCC), menghambat influx $\mathrm{Ca}^{2+}$ pada post sinaps atau menghambat influx $\mathrm{Ca}^{2+}$ presinaps, kemudian menghambat pelepasan neurotransmitter eksitatory sehingga menumpulkan transmisi sinaptik. Hal tersebut menyebabkan penurunan pelepasan neurotransmitter eksitatory yaitu neurotransmitter glutamate dan neurotransmitter noradrenalin, dan meningkatkan neurotransmitter inhibisi yaitu GABA.

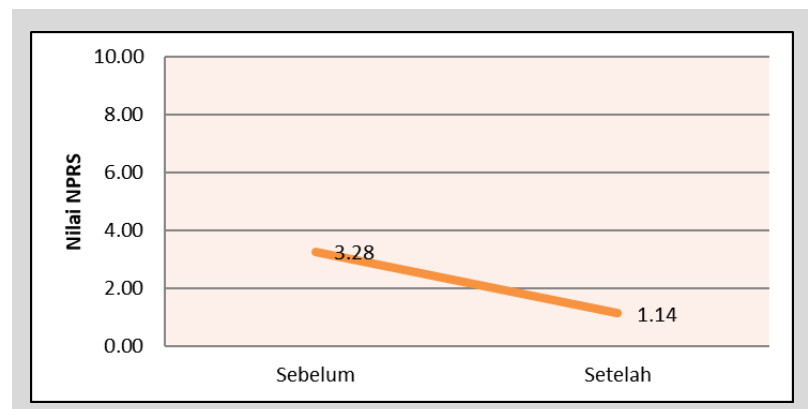

Gambar 1. Kurva penurunan nilai NPRS sebelum dan setelah pemberian Gabapentin.

\section{KESIMPULAN}

Pemakaian gabapentin pada pasien neuropati diabetik di poli klinik endokrin dan poli klinik saraf di RSUP Wahidin Sudirohusodo Makassar menunjukkan penurunan skala nyeri yang diukur dengan Numerical Pain Rating Scale (NPRS) dengan penurunan rata-rata sebesar 2,14 dengan nilai pvalue $<0,05$ yang berarti berbeda secara signifikan dalam menurunkan nyeri neuropati. Sedangkan efek Samping yang terjadi setelah pemberian gabapentin yaitu, mengantuk dan pusing $14 \%$, mengantuk 29\%, pusing $5 \%$ dan tidak mengalami efek samping $52 \%$.

\section{DAFTAR PUSTAKA}

1. Day, J. 2001. Living with diabetes. The diabetes UK guide for those treated with diet and tablets. London: WILEY.

2. Black, J.M., \& Hawks, J. 2009. Medical-surgical nursing: Clinical management for positive outcomes, Eight edition. Singapore: Saunders Elsevier.

3. Lemone, P. \& B. 2008. Medical surgical nursing: Critical thinking in client care. (4th ed). New Jersey.: Pearson Prentice Hall.

4. Argoff, C.E., Cole,B.E., Fishbain, D.A., \& Irving, G. A. 2006. Diabetic Peripheral Neuropathy Pain: Clinical and quality of life issuese. Mayo Clinic Proceeding, Vol. 81, No. 4.

5. Boyle J, Eriksson ME, Gribble L, Gouni R, Johnson S, Cappini DV, Kerr D. 2012. Randomized, Plasebo-controlled Comparison of Amitriptilin, duloxetin and pregabalin in Patient with Chronic Diabetic Peripheral Neuropathic Pain: Impact on Pain, Polysomnographic sleep, daytime functioning and quality of life. Diabetes Care:35: 2451-2458 
6. Moore RA, Wiffen PJ, Derry S, Toelle T, Rice AS. 2014. Gabapentin for Chronic Neuropathic pain and Fibromyalgia in Adults. Cochrane Database Syst Rev 2014;4:CD007938

7. Bril V, England J, Franklin GM, et al. 2011. Evidence based guideline: Treatment of painful diabetic neuropathy: report of the American academy of neurology, the American Association of Neuromuscular and Electrodiagnostic Medicine and the American Academy of physical Medicine and Rehabilitation. Neurology: 76:1758-1765.

8. Boulton., A., J., M. 2005. Management of diabetic Pheriferal neurophaty. Clinical Diabetes.

9. Haslam, C., and T. Nurmikko. 2008. Pharmacological treatment of neuropathic pain in older persons. Clinical Interventions in Aging 3: 111120.

10. Kukkar A, et al. 2013. Implications and mechanism of action of gabapentin in neuropathic pain. Arch Pharm Res. Mar;36(3):237-51

11. Harden, R.N. 2005. Chronic Neuropathic Pain - Mechanisms, Diagnosis, and Treatment. The Neurologist, Vol. 11, No. 2.

12. Chen H. 2004. Contemporary Management of Neuropathic Pain for the Primary Care Physician. Mayo Clin Proc, Vol. 79: 1533-1545
13. Gilron, I., 2005. Morphine, Gabapentin or Their Combination for Neuropathic Pain..N Engl J Med, Vol. 352., No. 13

14. 14 Ankes. Moretha, Rina. 2011. Obat-Obat dengan Indikasi Tidak lazim (Off- Label). Dapur farmasi. Jakarta.

15. Sugiono. 2005. Statistika Untuk Penelitian. ALFABETA. Bandung

16. Faucett, J., Gordon, N., \& Levine, J. (2009). Differences in postoperative pain severity among four ethnic groups. Pain Management.

17. Backonja M-M.1999. Gabapentin monotherapy for the symptomatic treatment of painful neuropathy: a multicenter, double-blind, placebocontrolled trial in patients with diabetes mellitus. Epilepsia 40:S57-S59

18. Anonim. 2010. FAQs about Gabapentin for Pain Relief. Cambridege University Hospitals NHS Foundation Trust.

19. Brunner dan Suddarth. 2001. Keperawatan Medikal Bedah, Edisi 8 Volume 2. Penerbit Buku Kedokteran EGC. Jakarta.

20. Dipiro et al, 2008, Pharmacotherapy: A Pathophysiologic Approach, 7th ed., Mc Graw Hill, New York.

21. American Diabetes Association (ADA). 2011. Diagnosis and Classification of Diabetes Melitus. Diabetes Care. 